\title{
PERANCANGAN MEDIA EDUKASI MITIGASI BENCANA DENGAN PENDEKATAN DESAIN PARTISIPATIF DI KECAMATAN BOJONGSOANG
}

\author{
Rahmatsyam Lakoro ${ }^{1}$, Agus Sachari ${ }^{2}$, Agung Eko Budiwaspada ${ }^{3}$, Setiawan Sabana ${ }^{4}$ \\ ${ }^{1}$ Departemen Desain Komunikasi Visual, Institut Teknologi Sepuluh Nopember \\ 2,3,4 Program Doktor IImu Seni Rupa dan Desain, Fakutas Seni Rupa dan Desain, \\ Institut Teknologi Bandung \\ djangkarock@gmail.com ${ }^{1}$
}

\begin{abstract}
Abstrak
Kawasan Sungai Citarum di Jawa Barat memiliki karakteristik bencana hidrometeorologi yang khas terkait kualitas air. Edukasi kesiapsiagaan dan pengetahuan tentang bencana menjadi hal yang mutlak, dikaitkan dengan siklus manajemen bencana, yaitu pada tahap pra-bencana. Kelompok budaya yang berbeda memiliki kepercayaan yang berbeda-beda pula tentang bagaimana menghadapi bencana, sehingga seringkali merespon sebuah fenomena bencana dengan cara yang tidak diduga oleh masyarakat modern. Pendekatan desain partisipatif digunakan untuk melakukan edukasi bencana dengan nilai-nilai setempat pada masyarakat Sunda khususnya Kecamatan Bojongsoang. Pelibatan partisipan dari kelompok protagonis memungkinkan pesan dikembangkan, diproduksi dan didistribusikan oleh masyarakat setempat. Pengembangan media poster, animasi, poster digital berbasis media sosial dan buku memiliki karakteristik yang berbeda sehingga penelitian ini juga dapat menemukan rekomendasi strategi media dan metode desain yang spesifik-tempat untuk kampanye edukasi bencana hidrometeorologi. Konsep yang lahir dari penelitian kemudian digunakan sebagai rekomendasi untuk melakukan proses desain berikutnya terkait metode dan pendekatan desain, desain visual, serta strategi media untuk menyampaikan pesan pada khalayak sasaran. Kelompok protagonis dilibatkan dalam distribusi pesan pada masyarakat di daerahnya. Pengetahuan dan pengalaman partisipan yang berada di lingkungan komunitasnya memperkaya desain, produk komunikasi, dan pendekatan dalam konten edukasi yang ditampilkan dalam kampanye sosial.
\end{abstract}

Kata Kunci: desain partisipatif, media edukasi, mitigasi bencana

\begin{abstract}
The Citarum River area in West Java has typical hydrometeorological disaster characteristics related to water quality. Education on disaster preparation and knowledge are essential, linked to the disaster management cycle, as part of the pre-disaster stage. Different cultural groups have different beliefs about the concepts of dealing with disaster, so they often respond to a catastrophic phenomenon in ways that modern society does not expect. The participatory design approach was used to implement disaster education with local values in the Sundanese community, especially in Bojongsoang Regency. The involvement of participants from the protagonist group allows messages to be developed, produced, and distributed by the community. The development of media posters, animations, digital posters based on social media and books have different characteristics that can also find strategic recommendations on media and design methods that are site-specific for hydrometeorological disaster education campaigns. The concept was born from the research is then used as a recommendation to carry out the next design process related to design methods and approaches, visual design, and media strategies to convey the message to the target audience. The protagonist group is also involved in the distribution of information to the community in the area. Participants' knowledge and experience in their living space, enrich the design, communication products, and educational content in the social campaign.
\end{abstract}


Keywords: disaster education, educational media, mitigation, participatory design

\section{PENDAHULUAN}

Menurut Badan Nasional Penanggulangan Bencana (BNPB), 92\% bencana di Indonesia yang tercatat dari tahun 1815 hingga 2017 adalah bencana hidrometeorologi. Bencana tersebut berdampak pada kerusakan infrastruktur, hambatan transportasi di darat dan laut, ketidakamanan energi, fluktuasi produksi pangan, dan kemunduran stabilitas ekonomi (BNPB, 2019). Meskipun letak Indonesia secara geografis berada di daerah pertemuan lempeng Eurasia, lempeng Samudera Pasifik, dan Indo-Australia yang rawan terhadap bencana atau dikenal dengan daerah Cincin Api (the ring of fire), frekuensi bencana hidrometeorologi lebih tinggi dibanding jenis bencana yang lain.

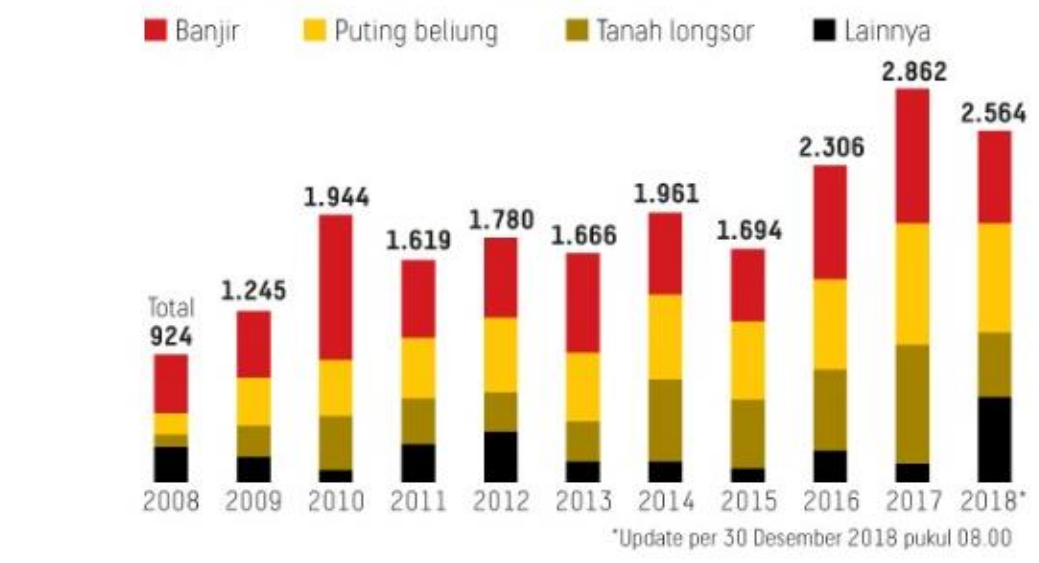

Gambar 1. Kejadian Bencana di Indonesia Didominasi Bencana Hidrometeorologi [sumber: BNPB, 2018]

Masyarakat yang secara geografis hidup di daerah bencana, umumnya memiliki perencanaan menghadapi bencana yang dijalankan secara tradisional. Pola dalam sebuah komunitas dan kelompok sosial dapat memengaruhi pola-pola pemberian bantuan, edukasi dan konsumsi media. Bagi masyarakat yang sudah pernah mengalami bencana alam, media edukasi ini dapat memperkuat pengetahuan atas pengalaman selama terkena bencana. Bagi masyarakat yang belum pernah mengalami bencana, media edukasi ini dapat meningkatkan awareness terhadap tindakan yang harus dilakukan ketika bencana terjadi. Tidak pernah terbayangkan bagaimana bencana terjadi dan dampaknya secara keseluruhan. Selain berdampak secara fisik, dampak psikologis jauh akan lebih membutuhkan waktu lama untuk pulih.

Informasi yang berhubungan dengan seluruh tindakan sebelum bencana, saat bencana terjadi dan rehabilitasi pasca bencana dapat menjadi materi edukasi pada game kecakapan hidup menghadapi bencana. Salah satu teknik yang dikembangkan adalah intervensi psikososial (Ehrenreich, 2001) yaitu teknik Mereduksi Stress (Stess Reduction Techniques) dimana selain mengistirahatkan fisik, korban dapat mengistirahatkan kelelahan mental melalui permainan dan aktivitas rekreatif mulai dari bermain kartu, menonton televisi, hingga berpartisipasi dalam permainan tertentu. Hal ini berlaku 
untuk semua usia untuk mengembalikan perasaan normal pada korban serta kontrol atas hidup seseorang. Teknik ini akan dapat bekerja dengan bantuan profesional.

Dalam konteks edukasi bencana, riset mengenai elemen visual suatu kelompok masyarakat dapat diujikan sebagai perangkat edukasi yang bersifat visual. Motivasi ini memperjelas tujuan dari setiap media edukasi bencana yang diciptakan agar meninggalkan pemahaman yang membekas dalam jangka panjang. Salah satu contoh keberhasilan pengajaran bencana yang cukup terkenal adalah Tilly Smith, seorang anak kecil asal Inggris yang saat terjadi tsunami menghantam Pantai Maihkao, Phuket Thailand pada tahun 2004 usianya masih 10 tahun. Tilly Smith belajar mengenai tsunami di kelas geografi di sekolahnya Danes Hill School dari sang guru Andrew Kearney, dua minggu sebelum dia dan keluarganya pergi berlibur ke Thailand. Tilly menyelamatkan banyak orang saat dia menemukan gejala tsunami seperti yang dijelaskan gurunya di kelas. Saat laut mendadak surut dan keluar gelembung di pantai, Tilly berlari ke hotel dan memperingatkan orang tuanya dan tamu-tamu hotel, yang kemudian segera melakukan tindakan evakuasi untuk menjauh dari pantai (Khoirul M, 2019)

Media memungkinkan manusia menjadi satu-satunya mahluk di bumi yang dapat mengakumulasikan pengetahuan dan meneruskannya pada generasi berikutnya. Akumulasi pengetahuan tersebut seringkali membentuk dasar kebudayaan dan peradaban manusia (Wim Westera, 2015). Media tersebut dipandang sebagai material yang secara langsung maupun tidak langsung, konkret maupun abstrak, memberikan pengalaman dan dapat disebut sebagai perangkat bergambar. Kerucut pengalaman Edgar Dale (Dale, 1946) tidak menawarkan kesempurnaan gambar sebagai sebuah alat, tetapi bagaimana wahana visual menjelaskan hubungan antar material dan posisi individu dalam sebuah proses belajar. Dalam hal ini bukan berarti belajar dengan metode membaca adalah yang paling lemah, tetapi metode yang membuat pengetahuan sulit diingat dalam jangka waktu tertentu.

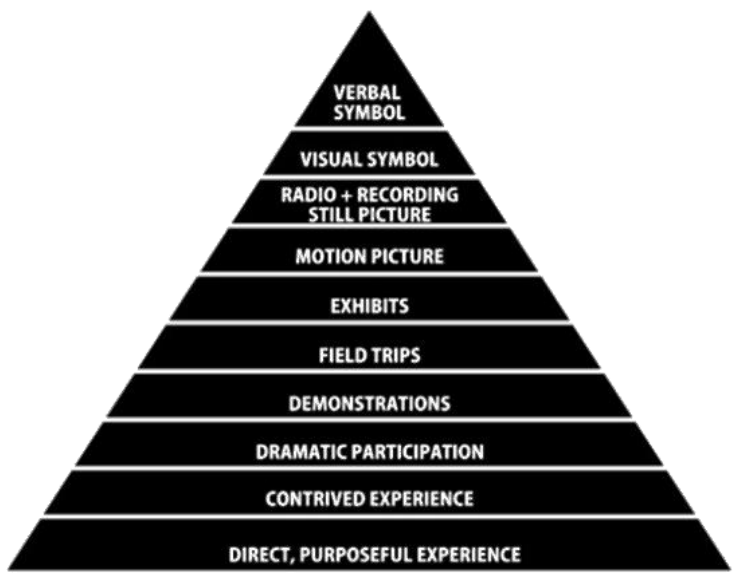

Gambar 2. Kerucut Pengalaman Edgar Dale [sumber: Dale, 1946:39]

Edukasi kebencanaan berbeda dengan edukasi yang umum karena produk komunikasinya perlu memenuhi fungsi kognitif tertentu untuk dipahami, memperoleh 
perhatian, terkait erat dengan situasi kedaruratan dan informasi yang terkait keselamatan, hidup dan mati. Dampak dari perancangan media edukasi bencana diharapkan memberi kebaruan sesuai dengan karakteristik masyarakat Indonesia dalam membangun kultur keselamatan. Kelayakan pengujian dan reproduksi dalam penelitian desain sifatnya tidak lebih penting dibandingkan sensitivitasnya terhadap konteks sosial dan momen kultural yang membuat hasil dari penelitian desain tersebut beresonansi dengan publik atau pasar. Sejalan dengan pandangan Laurel (2003) bahwa penelitian desain yang berpusat pada manusia dapat memperkuat kemampuan desainer untuk membentuk budaya populer dan secara halus mentransmisikan nilai-nilai melalui desain (Lunenfeld, 2003).

\section{METODE PENELITIAN}

Media yang disebarkan pada partispan dianalisa dengan kerangka Analisis Deskriptif Kualitatif pada elemen-elemen komunikasinya baik sebagai elemen verba maupun visual. Medan komunikasi dengan partisipan dibangun dengan pendekatan Action Research atau penelitian tindakan merupakan penelitian sosial yang dilakukan dengan kolaborasi antara peneliti profesional, organisasi, masyarakat dan jejaring pemangku kepentingan yang mencari cara untuk mengembangkan kondisi pada partisipan. Penelitian tindakan mengajukan partisipasi yang luas dalam proses penelitian dan mendukung aksi ke arah yang bukan sekadar memuaskan pemangku kepentingan. Peneliti dan pemangku kepentingan mendefinisikan permasalahan untuk diperiksa, bersama-sama saling mengembangkan pengetahuan yang relevan tentang permasalahan itu, melakukannya dengan teknik-teknik riset sosial, mengambil tindakan dan menafsirkan hasil dari aksi tersebut berdasarkan apa yang telah dipelajari (Greenwood \& Levin, 2007).

Menurut Smith dan Iversen (2018) membangun di atas nilai-nilai adalah inti dari desain partisipatif. Tiga dimensi keterlibatan pelingkupan (scope), pengembangan (development) dan penskalaan (scaling) menjadi penting dalam mengembangkan pendekatan holistik untuk desain partisipatif sebagai praktik berkelanjutan dari perubahan sosial (Smith \& Iversen, 2018). Tiga dimensi keterlibatan pelingkupan, pengembangan dan penskalaan, merupakan pendekatan desain partisipatif kontemporer, ditempuh dengan melakukan eksperimen dalam penelitian desain menuju komitmen yang lebih besar dan jangka panjang terhadap kualitas hidup dan memiliki dampak sosial, fokus inklusif pada praktik sosial, dan pengembangan sistem sosial-teknis yang kompleks dan jaringan aktor.

Dimensi pertama dari tiga dimensi keterlibatan dalam desain partisipatif untuk perubahan berkelanjutan adalah Scope/ Pelingkupan: dari keterlibatan pengguna hingga komunitas protagonis. Dimensi ini berfokus pada menciptakan ruang mutualitas di mana peserta yang beragam dapat mengeksplorasi dan melatih masa depan yang potensial bersama dan mengembangkan arah yang sesuai dengan tujuan dan aspirasi, sambil mempertahankan agen/informan/ partisipan dan membangun jaringan. Dimensi kedua, Development/ Pengembangan: dari artefak teknologi ke praktik digital dan konsepsi teknologi, menekankan dimensi proses dari pengembangan hasil nyata dan tidak 
berwujud, tidak ditentukan sebelumnya sebagai artefak teknologi, tetapi disesuaikan dengan konsep kritis teknologi dan produksi literasi budaya digital baru secara spesifik sesuai konteks. Dimensi ketiga, Scaling/ Penskalaan: dari hasil nyata hingga perubahan sosial berkelanjutan, berfokus pada penciptaan berbagai peluang untuk mempertahankan dan meningkatkan proyek, di luar partisipan pelaku individu, dalam komunitas yang lebih besar dan lintas domain dan pemangku kepentingan di berbagai tingkat otoritas. Kampanye sosial kebencanaan berbeda dengan edukasi yang umum karena produk komunikasinya perlu memenuhi fungsi kognitif tertentu untuk dipahami dan memperoleh perhatian dan terkait erat dengan situasi kedaruratan dan informasi yang terkait keselamatan.

Data yang dikumpulkan bersifat kualitatif terdiri atas wawancara dengan berbagai pihak, antara lain tokoh masyarakat, aktivis lingkungan, kelompok sasaran yang masuk dalam komunitas protagonis, pihak pemerintah yang terkait kebencanaan atau peringatan dini. Data verbal yang bersifat kuantitatif terdiri atas hasil survei dengan instrumen kuesioner untuk menggali pengalaman, sikap, kebiasaan dari komunitas yang disasar dalam kampanye. Data visual yang bersifat kualitatif berasal dari observasi peneliti terhadap partisipan, model-model mitigasi yang berjalan, video dan foto. Data visual yang bersifat kuantitiatif diperoleh dari data sekunder mengenai wilayah Kecamatan Bojongsoang dikaitkan dengan kebencanaan. Dalam prosesnya, penelitian ini berada dalam masa sulit ketika terjadi pandemi Covid-19 yang tidak memungkinkan interaksi langsung antara peneliti dan partisipan penelitian. Peneliti kemudian mengembangkan berbagai metode partisipatif dalam proses desain melalui pemanfaatan jejaring media sosial. Jejaring sosial dan media sosial yang luas menawarkan kemungkinan yang hampir tidak terbatas untuk berbagi dan kolaborasi daring. Interaksi dengan partisipan digunakan untuk mengevaluasi desain yang sudah ada, desain yang akan dikembangkan, hingga melaukukan validasi desain, dan hal ini memberi kesempatan peneliti melihat berbagai kemungkinan yang dapat diterapkan dalam rancangan.

Proses mendesain dalam penelitian ini berupaya mencapai tujuan dengan pendekatan desain berpusat pada manusia (human centered design), studi komunikasi visual dengan analisis deskriptif kualitatif pada berbagai media komunikasi visual terkait konten media kampanye sosial mitigasi bencana. Penelitian ini bertujuan memperbesar kontribusi ilmu seni rupa dan desain pada edukasi mitigasi bencana di Indonesia. Topik kampanye sosial mitigasi bencana telah dikerjakan beberapa peneliti yang terkait langsung, misalnya yang terkait dengan disiplin kebumian. Penelitian terkait media kampanye strategis kebencanaan dilakukan dengan pendekatan etnografis dengan karakteristik beragam pada sampel yang diambil.

Menurut Greenwood \& Levin (2007) penelitian tindakan merupakan keseimbangan antara 3 elemen penting yakni (1) Aksi, dimana penelitian tindakan ini merupakan penelitian partisipatif, karena tujuannya membuat situasi awal yang berbeda dengan kelompok, organisasi, komunitas dengan arah mencapai kondisi untuk mengelola diri, membebaskan dan berkelanjutan; (2) Penelitian, dimana penelitian dipercaya memberi kekuatan dan nilai dari pengetahuan, teori, model, metode dan analisis, sehingga 
diharapkan menghasilkan pengetahuan baru; serta (3) Partisipasi, dimana penelitian partisipatif menempatkan nilai kuat dalam demokrasi dan kendali atas kondisi hidup seseorang. Nilai ini meneguhkan argumen dan komitmen kuat untuk demokratisasi proses produksi pengetahuan. Penelitian tindakan melibatkan peneliti sosial yang melayani masyarakat dan organisasi, baik sebagai fasilitator maupun pengajar. Produksi pengetahuan menjadi penting untuk mengubah situasi dan penelitian tindakan melibatkan semua orang untuk berpartisipasi serta mengambil tanggung jawab.

Untuk mencapai keseimbangan antara tiga elemen penting yakni Aksi, Penelitian dan Partisipasi, dilakukan eksperimen visual terhadap beberapa media edukasi kebencanaan hidrometeorologi. Berdasarkan beberapa literatur kebencanaan resmi milik Badan Nasional Penanggulangan Bencana, ditentukan konten media yang mendesak untuk menjadi pesan dalam kampanye ini, yaitu pengendalian sampah, pemahaman siklus prabencana dan pengetahuan bencana hidrometeorologi. Dalam elemen (1) Aksi, peneliti membangun medan komunikasi dengan komunitas protagonis Gerakan Pramuka di salah satu sekolah menengah pertama di Bojongsoang. Situasi awal adalah komuitas yang belum memahami perlunya pengelolaan sampah domestik diberi pengetahuan dan diajak berpartisipasi dalam mengurangi sampah domestik tersebut, dan direncanakan sebagai suatu gerakan lingkungan yang berkelanjutan. Aksi, dimana penelitian tindakan ini merupakan penelitian partisipatif, karena tujuannya membuat situasi awal yang berbeda dengan kelompok, organisasi, komunitas dengan arah mencapai kondisi untuk mengelola diri, membebaskan dan berkelanjutan; dalam elemen (2) Penelitian, peneliti menggunakan kuesioner untuk menggali preferensi media yang dekat dengan komunitas protagonist tersebut sehingga memberikan arah rekomendasi mengenai media yang tepat digunakan sebagai pembawa pesan kampanye dan edukasi bencana; serta pada elemen (3) Partisipasi, peneliti melibatkan komunitas protagonis tersebut untuk memroduksi literatur kebencanaannya sendiri dengan belajar membangun pengetahuan atas kebencanaan khas di wilayahnya. Peneliti mendesain bersama para partisipan untuk memperoleh luaran desain yang mewakili kebutuhan partisipan.

Dalam penelitian tindakan dapat dijabarkan secara rinci sebagai berikut:

1. Karakteristik Permasalahan

Permasalahan didefinisikan dalam penelitian tindakan sebagai sesuatu yang penting bagi partisipan, atau proses tidak akan berjalan baik. Apabila telah dilakukan, peneliti dapat menambahkan pengetahuan yang relevan di lapangan, misalnya dalam kasuskasus dari budaya literasi di suatu komunitas. Peneliti melakukan wawancara dengan pemangku kepentingan terkait edukasi kebencanaan hidrometeorologi untuk melihat problematika secara komprehensif, dan bersama partisipan bersama-sama melihat kembali permasalahan tersebut sebagai suatu proses belajar. Untuk mencapai hal tersebut, prosedur komunikasi dibentuk sebagai kesepakatan akan fokus permasalahan yang dihadapi. 


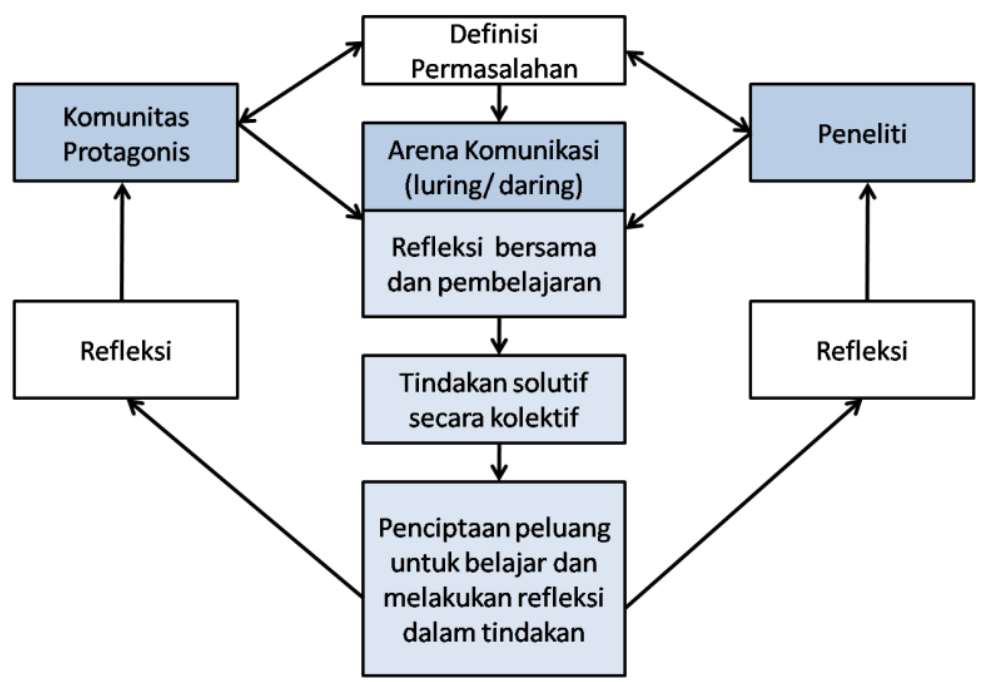

Gambar 3. Adaptasi Peneliti atas Cogenerative Action Research Model [sumber: Greenwood \& Levin: 2007:94]

\section{Arena Komunikasi}

Pusat dari proses kogeneratif dalam penelitian tindakan adalah kemampuan untuk menciptakan ruang untuk proses belajar yang dihasilkan dari interpretasi dan perencanaan yang dipercayai oleh partisipan. Arena komunikasi antar kelompok yang terlibat dalam penelitian harus diperjelas sejak awal. Arena ini menjadi lokasi dimana semua aktor dalam penelitian bertemu satu sama lain dengan material yang telah dirancang sesuai tujuan penelitian tindakan. Arena tersebut dapat berupa pertemuan antara dua orang atau lebih dalam suatu sesi penyuluhan, diskusi, pertemuan gugus tugas, atau pertemuan dengan masyarakat. Hal yang penting di arena komunikasi ini adalah memberi ruang untuk berkomunikasi dan mengambil tempat dalam struktur lingkungan yang memungkinkan proses pembelajaran kogeneratif dan penelitian tindakan.

Selain pengambilan data, media sosial ini kemudian digunakan peneliti untuk melakukan edukasi mitigasi bencana hidrometeorologi bahkan sosialisasi Covid-19. Menurut DeMarcos dkk, (2016) pemanfaatan jejaring sosial populer mempercepat interaksi siswa, siswa dan guru, komunikasi dan kolaborasi untuk meningkatkan sikap siswa (DespotovicZrakic, Labus, \& Milic, 2011 pada de Marcos dkk, 2015). Selain itu, jejaring pendidikan berdampak pada motivasi, retensi, keterlibatan, kepuasan siswa, kreativitas individu dan interaksi pribadi, meningkatkan efisiensi komunikasi dan memfasilitasi sudut pandang yang berbeda (Brady, Holcomb, \& Smith, 2010 pada deMarcos dkk, 2015). Posisi individu yang dimiliki setiap siswa di jaringan juga penting, memengaruhi pembelajaran sosial (Paredes \& Chung, 2012 pada deMarcos dkk, 2015), kinerja belajar (Cho, Gay, Davidson, \& Ingraffea, 2007 pada deMarcos dkk, 2015) dan bahkan kreativitas (Gaggioli, Mazzoni, Milani, \& Riva, 2015 pada deMarcos dkk, 2015). Selain itu dalam proses penelitian yang partisipatif ada kecenderungan seperti yang diungkap Irwandi dkk, (2020) bahwa konstruksi makna dipersepsikan dan diekspresikan melalui semangat komunal dan kolektif, berdasarkan pengalaman bersama, berdasarkan hubungan sosial yang ada di tempat yang dipengaruhi oleh sejarah, budaya, lanskap serta faktor ekonomi 


\section{HASIL DAN PEMBAHASAN}

Hasil-hasil wawancara dengan berbagai pemangku kepentingan digunakan sebagai dasar untuk proses kreatif berikutnya yaitu proses eksperimentasi desain. Berbagai kriteria desain muncul dari wawancara dan diskusi dengan partisipan.

\subsection{Analisis Deskriptif Kualitatif}

Penelitian desain yang dilakukan menghasilkan beberapa temuan dan data yang diperoleh dari wawancara dengan narasumber dari berbagai pihak. Data tesebut kemudian dianalisis secara deskriptif sebagai berikut:

Tabel 1. Ringkasan Wawancara dengan Ahli Mitigasi Bencana

[sumber: Dokumentasi peneliti, 2017]

\begin{tabular}{|c|c|c|}
\hline \multicolumn{2}{|c|}{ Narasumber } & Partisipan 1, Ahli Mitigasi Bencana \\
\hline \multicolumn{2}{|c|}{ Waktu Wawancara } & April 2017 \\
\hline \multicolumn{2}{|c|}{ Topik } & Media edukasi mitigasi bencana \\
\hline No & Sub Topik & Ringkasan Wawancara \\
\hline 1 & $\begin{array}{l}\text { Media } \\
\text { kampanye } \\
\text { strategis } \\
\text { mitigasi } \\
\text { bencana }\end{array}$ & $\begin{array}{l}\text { Media kampanye strategis mitigasi bencana yang selama ini diterapkan } \\
\text { pada masyarakat dipandang sebagai upaya edukasi mitigasi bencana, } \\
\text { reaksi para pemimpin/pemerintah biasanya berupa ajakan mewaspadai } \\
\text { cuaca ekstrim. Tetapi seringkali tidak informatif mengenai hal-hal apa } \\
\text { yang perlu diwaspadai. Ada kecenderungan, setelah mengatakan } \\
\text { waspada, seolah kewajiban pemerintah jadi hilang. Bentuk konkret dari } \\
\text { edukasi itu bias berupa penugasan Pemerintah daerah kepada SKPD di } \\
\text { daerahnya untuk meninjau kesiagaan masyarakat menghadapi } \\
\text { bencana. }\end{array}$ \\
\hline 2 & $\begin{array}{l}\text { Media yang } \\
\text { ideal } \\
\text { digunakan } \\
\text { untuk } \\
\text { edukasi }\end{array}$ & $\begin{array}{l}\text { Masyarakat harus diajari. Bukan sekedar menyiapkan logistik, tetapi } \\
\text { upaya antisipasi. Problemnya juga, masyarakat kita seringkali tidak } \\
\text { melihat itu sebagai masalah. Tindakan konkret lainnya yang dapat } \\
\text { diambil seperti yang telah dilakukan di Kementerian ESDM. } \\
\text { Kementerian ESDM sudah menyediakan peta rawan bencana, BMKG } \\
\text { sudah memberi informasi kapan bencana akan datang, curah hujan } \\
\text { berapa besar. Tindakan berikutnya adalah menyiapkan masyarakat } \\
\text { menghadapi itu. Sehingga ada dalam kondisi bahwa masyarakat juga } \\
\text { melihatnya sebagai masalah. Selama ini, bila hanya bersifat informatif } \\
\text { kemungkinan akan terulang lagi. Hasil edukasi diharapkan bukan } \\
\text { sekadar menjadi pengetahuan tapi memahami tindakan yang harus } \\
\text { diambil saat bencana. }\end{array}$ \\
\hline 3 & $\begin{array}{l}\text { Contoh kasus } \\
\text { pembelajaran } \\
\text { bencana yang } \\
\text { ideal }\end{array}$ & $\begin{array}{l}\text { Tilly Smith itu contoh hasil edukasi bencana yang baik. Perlu ada yang } \\
\text { bisa mengemas edukasi yang mudah dipahami masyarakat. Kalau } \\
\text { edukasi bencana tersebut masuk jadi bagian dari kurikulum seharusnya } \\
\text { dikemas menjadi edukasi sederhana yang mudah diterima seperti di } \\
\text { Jepang yang dikenal memiliki budaya tangguh menghadapi bencana. } \\
\text { Pemerintah bisa berpotensi menjadi baik dalam penanganan bencana, } \\
\text { tetapi ketika ada kecenderungan menutup beritanya, budaya } \\
\text { keselamatan yang tumbuh di masyarakat kita hanya respon saja bukan } \\
\text { antisipasi. Membalik respon menjadi antisipasi itu yang butuh waktu. } \\
\text { Kita harus menempuh berbagai macam cara dalam edukasi bencana ini. }\end{array}$ \\
\hline
\end{tabular}


Media pembelajaran untuk mitigasi pada masyarakat umum perlu lebih konkret dan komunikatif. Komunitas tertentu dalam masyarakat dapat membantu pemerintah untuk menghasilkan pesan-pesan yang mudah dipahami. Selain itu peran sekolah juga besar untuk memberikan pemahaman yang benar tentang bencana. Edukasi bencana yang berada dalam tahap prabencana menjadi vital karena diharapkan dapat membentuk budaya keselamatan dan menjadikan kebiasaan merespon bencana menjadi sikap antisipatif untuk mengurangi resiko bencana yang disebut mitigasi. Dari masing-masing pihak harus bisa mengeluarkan Standard Operational Procedure (SOP) tentang bagaimana menghadapi bencana. Setiap unsur harus terinformasi dengan baik, bahkan secara tertulis juga membuat laporan wilayah yang aman di tempatnya. Ada kearifan lokal yang harus dipahamkan agar mampu beradaptasi dengan pendekatan dalam pengurangan risiko bencana (Disaster Risk Reduction). Hal ini hanya dapat dicapai dengan pendekatan edukasi bencana yang tepat.

Hasil analisis deskriptif dari wawancara dengan narasumber dari aktivis Seni Partisipatoris untuk Citarum adalah sebagai berikut:

Tabel 2. Ringkasan Wawancara dengan Aktivis Seni Partisipatoris

[Sumber: Dokumentasi peneliti, 2018]

\begin{tabular}{|c|c|c|}
\hline \multicolumn{2}{|c|}{ Narasumber } & Partisipan 2, Aktivis Seni Partisipatoris \\
\hline \multicolumn{2}{|c|}{ Waktu Wawancara } & Oktober 2018 \\
\hline \multicolumn{2}{|c|}{ Topik } & Seni Partisipatoris di Bojongsoang \\
\hline No & Sub Topik & Ringkasan Wawancara \\
\hline 1 & $\begin{array}{l}\text { Aktivitas Seni } \\
\text { Partisipatoris di } \\
\text { Bojongsoang }\end{array}$ & $\begin{array}{l}\text { Mural yang dikerjakan di kawasan Bojong Soang merupaan upaya } \\
\text { revitalisasi tradisi. Berlangsung selama } 9 \text { bulan dari tempat yang } \\
\text { penuh sampah dan gelap. Tujuannya adalah memberikan kesadaran } \\
\text { bahwa warga harus kembali menghidupkan sungai, dimana sungai } \\
\text { sebagai bagian depan dari rumahnya untuk dijaga kebersihannya. } \\
\text { Lokasi Bojong Soang adalah artefak dari Citarum dulu, sehingga harus } \\
\text { diabadikan dan mengingatkan kembali bahwa Sungai Citarum sebagai } \\
\text { sebuah pusat kebudayaan, dimana pertemuan antara Citarum dari } \\
\text { hulu Situ Cisanti dengan Sungai Cikapundung dari Kota Bandung. }\end{array}$ \\
\hline 2 & $\begin{array}{l}\text { Pesan dalam } \\
\text { Seni } \\
\text { Partisipatoris di } \\
\text { Bojongsoang }\end{array}$ & $\begin{array}{l}\text { Diharapkan dari aktivitas ini lahir koordinasi dengan pemerintah kota } \\
\text { di Bandung karena sungai memperlihatkan mentalitas warga. } \\
\text { Pencemaran Citarum adalah bencana internasional. Partisipan dalam } \\
\text { kegiatan ini sekitar } 30 \text { orang, terdiri atas mahasiswa, tentara, warga } \\
\text { hingga unsur pemerintahan. Bahkan melibatkan tokoh keagamaan } \\
\text { untuk menjadi semacam pengingat bahwa umat Islam sebagai } \\
\text { masyarakat mayoritas, setiap hari wudhu } 5 \text { kali tapi airnya tercemar. }\end{array}$ \\
\hline 3 & $\begin{array}{l}\text { Konsep spesifik } \\
\text { yang digunakan } \\
\text { dalam Seni } \\
\text { Partisipatoris }\end{array}$ & $\begin{array}{l}\text { Konsep secara keseluruhan dari aktivitas seni yang dilakukan } \\
\text { metodenya adalah revitalisasi tradisi. Tradisi yang pernah berjaya di } \\
\text { daerah ini ditumbuhkan kembali dalam semangat jaman muda, jaman } \\
\text { milenial. Seni ini mengandung nilai-nilai spriritual urban. Masyarakat } \\
\text { perlu diingatkan kembali bahwa Citarum ini dulunya memiliki seni } \\
\text { budaya yang membangun sikap peduli dengan alam. }\end{array}$ \\
\hline
\end{tabular}




\begin{tabular}{|c|l|l|}
\hline & & $\begin{array}{l}\text { Apabila banjir besar datang, sungai-sungai kecil dari utara } \\
\text { masalahnya adalah sampahnya, masyarakat menganggap sungai } \\
\text { sebagai tempat buang sampah. }\end{array}$ \\
\hline 4 & $\begin{array}{l}\text { Dampak Seni } \\
\text { Partsipatoris } \\
\text { pada } \\
\text { masyarakat }\end{array}$ & $\begin{array}{l}\text { Sikap masyarakat terhadap aktivitas ini nampak kurang peduli, tidak } \\
\text { ada inisiatif membantu tentara yang sudah bersusah payah } \\
\text { membersihkan Citarum. Kesadaran mereka kurang bahwa sungai } \\
\text { kotor akan membawa dampak pada saudara-saudaranya. Masyarakat } \\
\text { melihat tentara bukan sebagai mitra untuk memperbaiki lingkungan. } \\
\text { Nanti akan ada aktivitas kesenian, ada pertunjukan dan masyarakat } \\
\text { bisa berwisata di sana. Pada akhirnya akan menggerakkan } \\
\text { perekonomian masyarakat. Akan tetapi masalah sampah ini harus } \\
\text { disadarkan sebagai tanggung-jawab bersama. }\end{array}$ \\
\hline
\end{tabular}

Seni partisipatoris menjadi suatu pendekatan untuk membangun medan komunikasi yang positif di masyarakat karena sifatnya yang site-specific. Keterlibatan masyarakat di dalamnya akan membawa konsep-konsep tradisi yang telah direvitalisasi menjadi pesan yang sesuai dengan apa yang dipahami masyarakat. Menurut narasumber, koordinasi dengan pemerintah Kota dan Kabupaten Bandung untuk memperkuat dan menyadarkan warga karena Sungai Citarum dulu juga merupakan pusat kebudayaan sungai, misalnya di daerah Cigebar, pernah ada seorang dalang wayang bernama Abah Atmadja yang wafat tahun 1954. Ini salah satu indikasi adanya kegiatan seni budaya, dalam bentuk seni tradisi di bantaran Sungai Citarum.

Hasil analisis deskriptif dari wawancara dengan narasumber dari Badan Meteorologi, Klimatologi dan Geofisika (BMKG) adalah sebagai berikut:

Tabel 3. Ringkasan Wawancara dengan pihak BMKG

[Sumber: Dokumentasi peneliti, 2019]

\begin{tabular}{|c|c|c|}
\hline \multicolumn{2}{|c|}{ Narasumber } & Partisipan 3, Staf Data Geofisika BMKG \\
\hline \multicolumn{2}{|c|}{ Waktu Wawancara } & Oktober 2019 \\
\hline \multicolumn{2}{|c|}{ Topik } & Peran vital BMKG dalam EWS \\
\hline No & Sub Topik & Ringkasan Wawancara \\
\hline 1 & $\begin{array}{l}\text { Tugas BMKG } \\
\text { dalam siklus } \\
\text { kebencanaan }\end{array}$ & $\begin{array}{l}\text { Tugas utama BMKG bukan dalam aksi tanggap bencana tapi dalam } \\
\text { penyebaran informasi, jadi terkait dengan tupoksi kita dalam pra } \\
\text { bencana BMKG aktif dalam Early Warning System (EWS). Komunikasi } \\
\text { yang selama ini diterapkan ke masyarakat luas bila perangkat yang } \\
\text { dimiliki BMKG menangkap indikator potensi bencana adalah melalui } \\
\text { indikator yang sifatnya non-data, maksudnya sudah bersifat visual atau } \\
\text { peng-umuman. Sifatnya sebisa mungkin informatif, tidak bersifat } \\
\text { teknis. Ada visualnya berupa peta, ada juga yang disebarkan dalam } \\
\text { bentuk teks yang mudah dipahami masyarakat. Informasi ini } \\
\text { disebarkan ke seluruh Indonesia termasuk ke istana presiden. }\end{array}$ \\
\hline 2 & $\begin{array}{l}\text { Interaksi } \\
\text { dengan pihak } \\
\text { lain di ranah } \\
\text { kebencanaan }\end{array}$ & $\begin{array}{l}\text { Tugas BMKG sampai di tahap memberi informasi dari data } \\
\text { meteorology, klimatologi dan geofisika. Kewenangannya bukan pada } \\
\text { tindakan di lapangan, karena itu ranah BASARNAS dan BNPB. Prosedur } \\
\text { yang diterapkan bila indikasi-indikasi kebencanaan muncul adalah }\end{array}$ \\
\hline
\end{tabular}




\begin{tabular}{|l|l|l|}
\hline & $\begin{array}{l}\text { melalui pemutakhiran data, dari awal sampai berakhirnya potensi } \\
\text { kebencanaan. Informasi ini dapat diacu oleh pihak-pihak di lapangan } \\
\text { karena BMKG tidak dalam rantai komando dalam pengambilan } \\
\text { tindakan. BASARNAS selalu memantau informasi BMKG dan meminta } \\
\text { tenaga ahlinya untuk ikut menerjemahkan atau kira-kira memprediksi } \\
\text { cuaca dari keadaan kedaruratan tertentu. }\end{array}$ \\
\hline 3 & $\begin{array}{l}\text { Upaya yang } \\
\text { ditempuh } \\
\text { BMKG dalam } \\
\text { edukasi } \\
\text { bencana }\end{array}$ & $\begin{array}{l}\text { Upaya BMKG untuk memberikan edukasi kepada masyarakat tentang } \\
\text { resiko bencana yang telah berjalan selama ini berkaitan dengan peran } \\
\text { media. Informasi disajikan tetapi sebaiknya menghindari bentuk } \\
\text { komunikasi yang memunculkan kepanikan masyarakat. Kenyataannya, } \\
\text { masyarakat lebih percaya informasi dari WA grup, facebook. BMKG } \\
\text { sangat terbuka untuk memberikan edukasi, kunjungan sekolah atau } \\
\text { kunjungan mahasiswa. Media (cetak/elektronik/ audio visual/sosial) } \\
\text { yang digunakan untuk edukasi memang masih minim. Perlu dipikirkan } \\
\text { lebih jauh mengenai strategi komunikasi dan pengemasan informasi ke } \\
\text { masyarakat umum atau anak-anak. }\end{array}$ \\
\hline 4 & $\begin{array}{l}\text { Ada keluhan terkait kode kedaruratan yang belum ada kesamaan. } \\
\text { Persepsi level kedaruratan antara BMKG, BNPB, dengan BASARNAS } \\
\text { belum sinkron. Hal ini membuat golden time-nya tidak sama. Pihak } \\
\text { BMKG selau berdasarkan data, sementara piahk BNPB dan BASARNAS } \\
\text { berdasarkan event di lapangan. Perlu ada pendidikan yang berjenjang } \\
\text { kari mulai tingkat dasar sampai kuliah yang terkait dengan tindakan } \\
\text { betika } \\
\text { dengat menghadapi bencana. Ketika dikatakan bahwa Indonesia sebagai } \\
\text { lembaga } \\
\text { kebencanaan } \\
\text { lain }\end{array}$ & $\begin{array}{l}\text { supermarket bencana, seharusnya ada kurikulum kebencanaan di } \\
\text { sekolah yang berisi pengetahuan tentang bencana, resikonya dan } \\
\text { tindakan evakuasinya di sekolah. Bagi BMKG, peran media massa } \\
\text { penting untuk memberikan informasi sebagai respon peristiwa } \\
\text { kebencanaan secara proporsional. Posisi BMKG sebagai sumber } \\
\text { informasi bencana berdasarkan data seringkali diinterpretasi dengan } \\
\text { redaksi yang tidak terlalu tepat oleh pewarta yang mengambil sumber } \\
\text { dari rilis BMKG. Akibatnya, ketika terjadi kegaduhan di masyarakat, } \\
\text { pihak BMKG yang menjadi sumber informasi jadi dipersalahkan. }\end{array}$ \\
\hline
\end{tabular}

Masyarakat diyakini narasumber lebih memercayai berita di media sosial daripada informasi resmi dari badan pemerintah seperti BMKG. Kondisi ini memungkinkan sering terjadinya distorsi informasi bahkan misinfomrasi. Selain itu belum ada media yang dirancang secara khusus untuk petugas di BMKG ketika memberikan peringatan dini dengan turun ke masyarakat yang terindikasi menghadapi suatu kedaruratan bencana hidrometeorologi. Alat bantu visual untuk melakukan penerangan pra-bencana belum ada, meskipun ada kebutuhan dari masyarakat terhadap media tersebut.

\subsection{Eksperimen Visual}

Sebagai suatu penelitian tindakan, keseimbangan antara tiga elemen penting yakni Aksi, Penelitian dan Partisipasi, dilakukan eksperimen visual terhadap beberapa media edukasi kebencanaan hidrometeorologi. Berdasarkan beberapa literatur kebencanaan resmi milik Badan Nasional Penanggulangan Bencana, ditentukan konten media yang mendesak untuk menjadi pesan dalam kampanye ini, yaitu pengendalian sampah, pemahaman siklus prabencana dan pengetahuan bencana hidrometeorologi. 
Hasil analisis deskriptif dari eksperimen visual pada kelompok sasaran adalah sebagai berikut:

Tabel 4. Analisa Deskriptif Media Kampanye Poster

[Sumber: Dokumentasi peneliti, 2020]

\begin{tabular}{|l|l|l|}
\hline Media & Desain \\
\hline Konten utama \\
\hline
\end{tabular}

\begin{tabular}{|l|}
\hline Poster digital \\
\hline Tas Siaga bencana \\
\hline \multicolumn{2}{|c|}{ Analisa Deskriptif } \\
\hline
\end{tabular}

Poster ini awalnya dirancang untuk ditempatkan secara fisik di titik-titik strategis di wilayah penelitian, tetapi kemudian peneliti mengalami kendala Pandemi Covid-19 untuk melaksanakannya. Menurut hasil wawancara dengan pihak BMKG, kebutuhan untuk memperoleh informasi yang bersifat fisik seperti poster seringkali muncul dari kelompok masyarakat yang lebih dewasa, karena dapat diakses tanpa harus menggunakan perangkat elektronik.

Konten informasinya adalah Tas Siaga Bencana (TSB) menjadi kepentingan mendesak untuk memberi pemahaman mengenai kesiapsiagaan menghadapi bencana yang datang sewaktu-waktu. Item-item penting tersebut dikelompokkan untuk mempermudah pemahaman, diantaranya alat pelindung diri, alat kebersihan pribadi, alat pertolongan pada kecelakaan, alat komunikasi, pakaian dan makanan, surat berharga dan alat-alat serbaguna.

Figur Pertahanan Sipil diangkat sebagai penyampai pesan karena meskipun telah dibubarkan lewat Peraturan Presiden No.88 tahun 2014, figur 'Hansip' telah begitu lekat dengan masyarakat kita untuk situasi kedaruratan di lingkungan

Tanggapan Partisipan

Sebanyak $\mathbf{8 0 . 7 7 \%}$ partisipan menyatakan pernah mengetahui tentang Tas Siaga Bencana, sedang $19.23 \%$ partisipan belum pernah mendengar. Tetapi seluruh partisipan (100\%) tidak dapat menyebutkan dengan lengkap item-item apa yang harus ada dalam tas tersebut. Sebanyak $19.23 \%$ partispan mengaku mengetahui informasi TSB dari poster, sedangkan sebagian besar mengetahui dari simulasi yang pernah diajarkan dalam gerakan pramuka (42.31\%) dan mendengar obrolan di radio dan televisi (42.31\%), serta dari penyuluhan baik di sekolah maupun di lingkungan tempat tinggalnya (23.08\%). 
Tabel 5. Analisa Deskriptif Media Sosial

[sumber: Dokumentasi peneliti, 2020]

\begin{tabular}{|c|c|}
\hline Media & Informasi sekuensial IG Carrousel \\
\hline Distribusi & Maret 2020 \\
\hline Konten utama & Tas Siaga bencana \\
\hline & Analisa Deskriptif \\
\hline Alat Serba & $\begin{array}{l}\text { Media ini merupakan poster digital yang } \\
\text { informasinya disusun secara sekuensial (berurutan) } \\
\text { berupa slide dan memiliki perincian dari setiap } \\
\text { konten. Distribusinya melalui akun instagram } \\
\text { dengan strategi meningkatkan kontak pengguna } \\
\text { dengan media sosialnya, serta mempermudah } \\
\text { proses distribusi informasi. } \\
\text { Media ini menggunakan Bahasa Indonesia yang } \\
\text { baku dalam menyampaikan pesan. Konten } \\
\text { informasinya adalah perincian dari Tas Siaga } \\
\text { Bencana (TSB). Beberapa slide (10) ini } \\
\text { menampillkan item-item yang berada dalam } 1 \\
\text { kategori dikelompokkan dalam } 1 \text { slide. Struktur } \\
\text { konten berupa cover (informasi umum sebagai } \\
\text { judul konten) dan diikuti dengan rincinan konten. } \\
\text { Pemahaman isi TSB, diantaranya alat pelindung diri, } \\
\text { alat kebersihan pribadi, alat pertolongan pada } \\
\text { kecelakaan, alat komunikasi, pakaian dan makanan, } \\
\text { surat berharga dan alat-alat serbaguna akan } \\
\text { membantu partisipan memahami, dan mencoba } \\
\text { membuat sendiri di rumah. }\end{array}$ \\
\hline \multicolumn{2}{|c|}{ Tanggapan Partisipan } \\
\hline \multicolumn{2}{|c|}{$\begin{array}{l}\text { Sebanyak } 73.08 \% \text { partisipan menyatakan pernah memperoleh informasi kebencanaan di } \\
\text { wilayahnya, sedang } 26.92 \% \text { partisipan lainnya belum pernah. Hal ini karena informasi di } \\
\text { lingkungannya disampaikan kepada kepala keluarga atau orang tuanya. Sebanyak } 53.85 \% \\
\text { partisipan mengaku mencari sendiri informasi itu di internet, } 50 \% \text { mengaku memperoleh } \\
\text { dari grup pesan instan berupa whatsapp dan media sosial berupa facebook dan instagram. } \\
\text { Tidak ada pengguna twitter pada partisipan. Hanya } 11.54 \% \text { dari partisipan yang memperoleh } \\
\text { informasi itu dari aparat RT/RW di lingkungannya. Partisipan mengaku menyukai media ini } \\
\text { karena kedetailan informasi dan kemudahan menyebarluaskannya pada kerabat dan teman- } \\
\text { temannya. Berturut-turut dari yang paling disukai, partisipan menyatakan menyukai media } \\
\text { ini karena kedetailan informasi, gambar yang informatif dan kemudahan menyebarluaskan. }\end{array}$} \\
\hline
\end{tabular}


[sumber: Dokumentasi peneliti, 2020]

\begin{tabular}{|c|c|}
\hline Media & Informasi sekuensial IG Carrousel \\
\hline Distribusi & April 2020 \\
\hline Konten utama & Gejala, Penyebaran dan Protokol Covid-19 \\
\hline Desain & Analisa Deskriptif \\
\hline 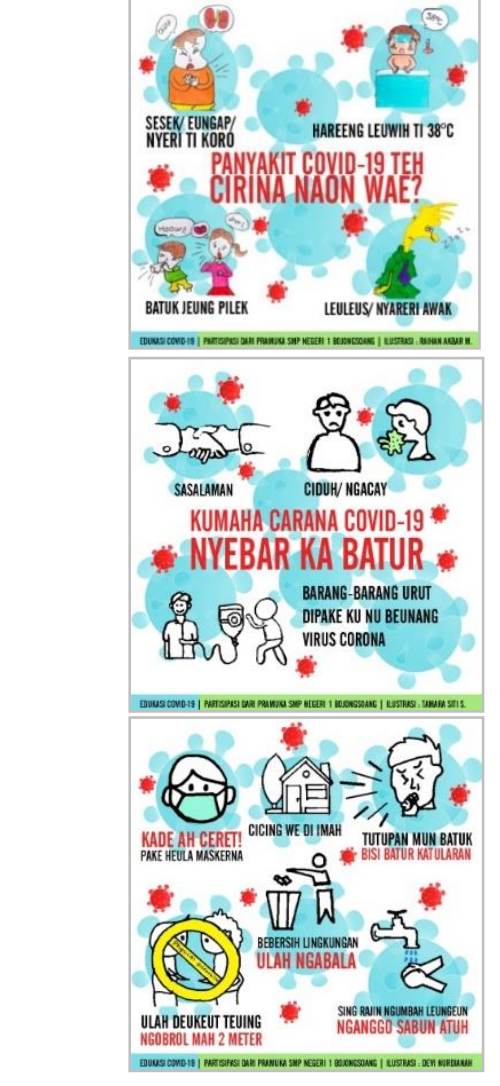 & $\begin{array}{l}\text { Media ini merupakan poster digital yang informasi } \\
\text { majemuk yang disusun dalam satu slide sesuai } \\
\text { kategori informasi. Sebagai respon atas } \\
\text { merebaknya pandemic Covid-19 ketika penelitian } \\
\text { berlangsung, peneliti mengajak partisipan } \\
\text { membuat informasi mengenai gejala, penyebaran } \\
\text { dan protokol Covid-19 dalam suatu infografis. } \\
\text { Distribusinya melalui akun instagram dengan } \\
\text { strategi meningkatkan kontak pengguna dengan } \\
\text { media sosialnya, serta mempermudah proses } \\
\text { distribusi informasi. } \\
\text { Media ini menggunakan Bahasa Sunda yang } \\
\text { bersifat informal dalam menyampaikan pesan pada } \\
\text { jejaring sosial yang dimiliki partisipan. Dalam } \\
\text { proses kreatifnya, peneliti memberikan informasi } \\
\text { dahulu kepada partisipan untuk direspon secara } \\
\text { bebas sebagai suatu visualisasi versi partisipan } \\
\text { sendiri. Hasil visualisasi partisipan kemudian diolah } \\
\text { peneliti dan diberi keterangan penjelas dalam } \\
\text { Bahasa Sunda. }\end{array}$ \\
\hline \multicolumn{2}{|c|}{ Tanggapan Partisipan } \\
\hline \multicolumn{2}{|c|}{$\begin{array}{l}\text { Peneliti mengajukan topik infografis ini dan partisipan merespon sesuai banyaknya informasi } \\
\text { yang ditentukan peneliti. Partisipan awalnya mengaku kesulitan melakukan visualisasi dari } \\
\text { narasi yang dikirimkan peneliti. Setelah dilakukan olah visual dan penyederhanaan konten, } \\
\text { partisipan mulai terlibat lebih jauh dalam proses kreatif media ini. Peneliti juga meminta } \\
\text { partisipan menyebarkan kepada minimal } 5 \text { kerabat dan teman di kontak pesan instannya. } \\
\text { Dengan } 26 \text { partisipan, diasumsikan pesan ini diterima oleh } 125 \text { orang dalam waktu yang } \\
\text { hampir serempak pada } 1 \text { jam pertama distribusi. }\end{array}$} \\
\hline
\end{tabular}

Dalam elemen (1) Aksi, peneliti membangun medan komunikasi dengan komunitas protagonis Gerakan Pramuka di salah satu sekolah menengah pertama di Bojongsoang. Situasi awal adalah komunitas yang belum memahami perlunya pengelolaan sampah domestik diberi pengetahuan dan diajak berpartisipasi dalam mengurangi sampah domestik tersebut, dan direncanakan sebagai suatu gerakan lingkungan yang berkelanjutan. Aksi, dimana penelitian tindakan ini merupakan penelitian partisipatif, karena tujuannya membuat situasi awal yang berbeda dengan kelompok, organisasi, komunitas dengan arah mencapai kondisi untuk mengelola diri, membebaskan dan 
berkelanjutan; dalam elemen (2) Penelitian, peneliti menggali preferensi media yang dekat dengan komunitas protagonist tersebut sehingga memberikan arah rekomendasi mengenai media yang tepat digunakan sebagai pembawa pesan kampanye dan edukasi bencana; serta pada elemen (3) Partisipasi, peneliti melibatkan komunias protagonis tersebut untuk memroduksi literatur kebencanaannya sendiri dengan belajar membangun pengetahuan kebencanaan khas di wilayahnya. Peneliti mendesain bersama para partisipan untuk memperoleh luaran desain yang mewakili kebutuhan partisipan.

\section{KESIMPULAN}

Kampanye sosial mitigasi bencana dengan pendekatan penelitian aksi dan desain partisipatif merupakan strategi yang dapat dikembangkan lebih jauh dengan pelibatan partisipan di wilayah bencana. Pengetahuan dan pengalaman partisipan berada di lingkungan tersebut dapat memperkaya desain, produk komunikasi dan konten edukasi yang ditampilkan dalam kampanye sosial. Sifat partisipan dan bencana yang spesifiktempat (site-specific) dapat menjadi kekuatan untuk merancang strategi desain yang sesuai untuk wilayah kebencanaan dan khalayak sasaran kampanye sosial yang berbeda. Metode ini diharapkan juga mengisi kesenjangan antara informasi dan masyarakat khalayaknya.

\section{DAFTAR PUSTAKA}

BNPB, P. (2019). Trend Bencana 2013-2017. January, 23. https://bnpb.go.id/trendbencana-2013-2017

Dale, E. (1946). Audio-Visual Methods in Teaching. Dryden Press.

De-Marcos, L., Garcia-Lopez, E., \& Garcia-Cabot, A. (2016). On the effectiveness of gamelike and social approaches in learning: Comparing educational gaming, gamification \& social networking. Computers and Education, 95, 99-113.

Ehrenreich, J. H. (2001). Coping with disasters - A Guidebook to Psychosocial Intervention (Revised Ed, Vol. 11568). Sharon McQuaide, M.S.W., Ph.D. Clinical Consultant.

Greenwood, D. J., \& Levin, M. (2007). Introduction to Action Research (2nd editio). Sage Publication, inc.

Irwandi, E., Sabana, S., Kusmara, A. R., \& Sanjaya, T. (2020). Respon Warga Terhadap Perubahan Visual. 06(02), 187-203.

Khoirul M, A. (2019). Berkat Pelajaran Geografi, Gadis 10 Tahun Ini Selamatkan 100 Nyawa Lebih dari Tsunami. https://intisari.grid.id/read/031672077/berkatpelajaran-geografi-gadis-10-tahun-ini-selamatkan-100-nyawa-lebih-daritsunami?page=all

Lunenfeld, P. (2003). The Design Cluster. In B. Laurel (Ed.), Design Research, Methods and Perspective.

Smith, R. C., \& Iversen, O. S. (2018). Participatory design for sustainable social change. Design Studies, 59, 9-36.

Wim Westera. (2015). Reframing the Role of Educational Media Technologies. Quarterly Review of Distance Education, 16(2), 19-32. 